\title{
COLONIAL GEOLOGY.
}

\section{AGE OF NEW SOUTH WALES COAL-BEDS.}

\section{By Mr. Datntren.}

The 'Yeoman, and Australian Acclimatizer,' publishes an article on the "Age of the New South Wales Coalfbeds," by Mr. Daintree, one of the gentlemen connected with the Geological Survey Department of this colony, from notes collected " during a three months trip from Melbourne to the Upper Burdekin, Queensland." One of the most important facts mentioned in these notes refers to the dispute which has been long pending between the Rev. Mr. Clarke, of New South Wales, and Professor $M^{\circ} \mathrm{Coy}$, as to the age of the New South Wales coal-fields. It must be satisfactory to Mr. Clarke to find that a gentleman of Mr. Daintree's experience and undoubted qualifications has done something towards turning the dispute in his favour.

The history of this dispute, says our contemporary, deserves attention. The Rev. W. B. Clarke, of New South Wales, has long been distinguished as one of the best practical geologists in this hemisphere. In numerous instances he pointed out where gold deposits would be found long prior to their actual discovery. He had also examined and reported upon the conl-strata of the sister-colony, and from a careful observation of the strata in position, and by the character of the fossil remains, he had arrived at the conclusion that some-of the coal-beds of New South Wales are of the same age as the Lower Carboniferous series of Europe. Professor $M^{\prime} \mathrm{Coy}$, however, before he left England, had adopted a notion that the New South Wales coal is Oolitic, but that the marine fossils in the same neighbourhood, often found in contact with the coal-beds, are Lower Carboniferous. With a pertinacity almost amounting to stubbornness, Professor M'Coy has adhered to the notion he had formed. After the Professor removed to the southern hemisphere, he did not think it worth while to visit the coal-beds in dispute, but continued to controvert, often with unseemly and even reprehensible bitterness, the opinions of $\mathrm{Mr}$. Clarke, who took an early opportunity of asking European geologists to suspend their judgment in the matter for a time, as he felt perfectly convinced of victory in the end. Mr. Clarke's argument was, that the coal could not be Oolitic and the marine fossils Lower Carboniferous, for in one locality examined-namely, Russell's pits, Stony Creek, Maitland (and at other places) - the coal-seams, with the plants in dispute, lie a long way below the marine beds. Some years ago Mr. Clarke sent a section of the coal-strata to the Royal Society of Victoria. Professor M.Coy and Mr. Selwyn rejected it, on the pretence that there was a "fault" in the strata; and in the opening address of the president of the society (Sir Henry Barkly) in 1861, judgment was given against the opinions of $\mathrm{Mr}$. Clarke. Throughout the dispute, that gentleman has been often unfairly dealt with, and harder things have been said than have appeared in print. In vol.v.p. 107, of the Transactions of the Royal Society of Victoria, there is a passage in a paper by Professor $M^{\prime}$ 'Coy, pretending that $\mathrm{Mr}$. Clarke told him and Mr. Selwyn that the specimen produced by Mr. Clarke in proof of his opinion was one of plants belonging to beds from which it had fallen, or might have fallen, from the top to the bottom of the sliaft. Mr. Clarke replied to this statement, but it was afterwards repeated (vide $p$. 217, vol. v. of the Royal Society's 'Transactions), as if Mr. Clarke, who 
produced the specimen in proof of the age of the coal, conld have admitted that all he had said was untrue. The 'Australian Yeoman' is convinced that $\mathrm{Mr}$. Clarke is right, and congratulates him on his triumph over a stubborn foe.

Then follow the geological notes collected during a three months' leave of absence, spent in a trip from Melbourne to the Upper Burdekin, Queensland (with a plan and section), by Richard Daintree, field geologist, Victoria ; the substance of which is,-

Starting from Melbourne, the Tertiaries of Port Philip Heads, the Amygdaloids of Cape Schank and Philip Island, succeeded by the cliffs of the Cape Paterson Carbonaceous strata, were rapidly passed. Next, the granite of Wilson's Promontory and the low sandy Tertiaries of Gipps Land. The promontory of Cape Howe was scanned, in the hope that it would afford some connecting link between the eastern extension of the Carbonaceous strata of Gipps Land and the southern coal-fields of New South Wales, but, from the distance no sign of stratified rocks could be discovered.

Kiama was the first point where sedimentary strata, traversed apparently by dykes of so-called "older basalts," met the view ; they form part of the New South Wales coal-group. Here the Basalt relieves, with undulating slopes of rich agricultural soil, the usual sterile character of a Carboniferous area. From Kiama to Sydney, cliffs of sandstones of the coal-group afford sections showing the gradual ascent into upper beds, the "Hawkesbury Series" of Clarke, on which Sydney stands. Crocodile Head, six miles north from Jarvis Bay, is a worthy subject for an artist's pencil, so picturesque is the grouping of these rocks at that particular point. From Sydney to Newcastle, bold bluffs of the same formation give facility for studying this part of the series. From Newcastle to Stony Creek is but a short trip, and as there are sections on which $\mathrm{Mr}$. Clarke bases his evidence of the Palæozoic age of part, at least, of the New South Wales coal-seams, it is one of the necessary pilgrimages for the wandering geologist in search of truth. What I saw there I will state in as few words as possible. I saw three shafts on Mr. Russell's estate-ladder-shaft, working-shaft, and $200 \mathrm{ft}$. shaft. Ladder-shaft is $19 \mathrm{ft}$. below the level, and $132 \mathrm{ft}$. west of working-shaft. Working-shaft is $9 \mathrm{ft}$. below the level, and $360 \mathrm{ft}$. north-west of $200 \mathrm{ft}$. shaft. The dip of the strata is east $6^{\circ}$ south. Taking working-shaft as a pivot, ladder-shaft is $6^{\circ}$, and " $200 \mathrm{ft}$." shaft $39^{\circ}$ off the line of dip. Reducing these distances between the shafts to the corresponding distances on the dip, we have-ladder-shaft distant from working-shaft $132 \mathrm{ft}$. nearly, " $200 \mathrm{ft}$." shaft distant from working-shaft $280 \mathrm{ft}$. For details of the various strata passed through in these shafts see Clarke's 'Discoveries in Australia,' p. 53. Four coal-seams were cut in the several shafts. We may distinguish them as the $5 \mathrm{ft} .7 \mathrm{in}$. seam, splint seam, working seam, and bottom seam. Now the working seam, No. 16 and 18 of Clarke, is removed between ladder and working shafts. The top of this seam is struck in ladder-shaft at $24 \mathrm{ft} .4 \mathrm{in}$., and in working-shaft at $92 \mathrm{ft}$. 4 in. The. difference in level being $19 \mathrm{ft}$., will therefore give a dip of $49 \mathrm{ft}$. in a horizontal distance of $132 \mathrm{ft}$., or the relation of perpendicular to base of $1: 2 \cdot 7=$ dip of over $20^{\circ}$. As $5 \mathrm{ft} .7$ in. seam crops at the surface of ladder-shaft, it will not afford safe data for calculation of dip between it and working-shaft. In "working" shaft top of $5 \mathrm{ft}$. 7 in. seam is met with at $60 \mathrm{ft} .9$ in. from the surface, in " $200 \mathrm{ft}$." shaft at $153 \mathrm{ft}$., or, subtracting $9 \mathrm{ft}$. for difference of level, at $144 \mathrm{ft}$. This gives a difference of $83 \mathrm{ft}$. 3 in. in $280 \mathrm{ft}$. horizontal distance, or the relation of base to perpendicular $1: 3.363$. In "working-shaft," bottom of

VOL. VII. 
working-seam, with $2 \mathrm{ft}$. parting of sandstone, is reached at $97 \mathrm{ft}$. $10 \mathrm{in}$.; to which add $9 \mathrm{ft}$. difference of level $=106 \mathrm{ft}$. 10 in.; and in " $200 \mathrm{ft}$." shaft bottom of same seam, with $5 \mathrm{ft}$. parting of sandstone, is reached at $187 \mathrm{ft} .1 \mathrm{in}$., which gives a difference of $80 \mathrm{ft}$. $3 \mathrm{in}$. in $280 \mathrm{ft}$., or relation of base to perpendicular $1: 3 \cdot 48$. It will be seen from thicse figures that a higher dip prevails between "working" and "ladder" than between " working" and " $200 \mathrm{ft}$." shafts, and also that the strata intervening between " $5 \mathrm{ft}$. 7 in." and "working" seams vary in thickness, and that we cannot deal as with straight lines in the calculation of the general dip. I have therefore taken the mean between the dip of the " $5 \mathrm{ft}$. 7 in." and "working" seam, between "working " and " $200 \mathrm{ft}$." shafts, as the nearest approximation for calculating the outcrop of the different strata. This is $81 \mathrm{ft} .9 \mathrm{in}$. in $280 \mathrm{ft}$. The relation of perpendicular to base $1: 3 \cdot 425=16^{\circ}$ nearly. This places the outcrop of the lowest stratum (Clarke's No. 25) at a point $993 \mathrm{ft}$. S. $6^{\circ} \mathrm{W}$. from the top of Russell's " $200 \mathrm{ft}$." shaft, supposing the surface of the ground at the same level. Outcrop of top of bottom seam, $794 \mathrm{ft}$.; ditto, working seam, $611 \mathrm{ft}$.; ditto, splint seam, 573 $\mathrm{ft}$; d ditto, $5 \mathrm{ft} .7 \mathrm{in} ., 524 \mathrm{ft}$. And these are the positions assigned for the various outcrops in the accompanying plan and section. When the details of these shafts were first made known by Mr. Clarke as a proof of the Palæozoic age of the coal, Spirifera Fenestella, etc., being found in abundance above, and Glossopteris associated with and below the coal, it was suggested by Professor $\mathbf{M}^{\circ} \mathrm{Coy}$, that the data given by $\mathbf{M r}$. Clarke showed the existence of a fault between "working " and " $200 \mathrm{ft}$." shaft. and that possibly to this fault the reversion of beds might be due, but the Palæozoic character of the fauna was not called in question. This error arose from taking the absolute distance between the shafts (360 ft.) instead of the reduced distance to the line of dip of $280 \mathrm{ft}$. Referring to the extension of Russell's coal-seams to the northern railway, unfortunately at a point where no marked bed of Russell's series can be absolutely identified, we have an apparently unbroken series of strata dipping in the same direction, and at about the same angle, as those in Russell's coal-pits, extending from a point at 19 miles 72 chains from Honeysuckle Flat to 21 miles 37 chains from the same place, the beds furthest to the eastward dipping at a greater angle. This affords a thickness (taking the angle of dip at $16^{\circ}$ ) of $2365 \mathrm{ft}$. of strata, abounding in fossil fauna from bottom to top, very low down in which coal-seams with Glossopteris occur. Fossils from each of the cuttings on the railway and from Russell's shafts were procured, that paiæontologists may satisfy them. selves of their Europeun parallel. If it be admitted that the fauna found in the upper strata of these shafts is Palæozoic, then these coal-seams, at least, are Palæozoic, and Glossopteris has a much lower range than has hitherto been assigned it, except by Mr. Clarke. Neither does there seem any reason why Mr. Clarke should not place the Newcastle coal-seams (his No. 3 Carboniferous group) in the upper portion of this Stony Creek group, no known unconformity existing, since no fauna or flora typical of the Mesozoic period has, I believe, yet been found in the said No. 3. This brings me to the consideration of Mr. Clarke's present arrangement of the Carboniferous series of New South Wales. First. "Wianamatta beds" with insignificant coal-seams, the upper beds of which are the probable equivalents of our Otway, Bellerine, and Wannon beds, in which Glossopteris has not yet been found. Second. "Hawkesbury beds," with insignificant coal-seams, and no Glossopteris. To this series Mr. Clarke refers the Grampian sandstones of Victoria, though Mr. Selwyn places them with No. 4. (By Grampian sandstones I mean the beds constituting the 
sierra.) Third. "Carboniferous beds," containing the workable coalseams, with Glossopteris by far the most abundant fossil. In the lower portion of this series, four known coal-seams are interpolated with strata containing a fauna similar in character to that found in the Carboniferous Limestone of Europe. Fourth. "Lepidodendron beds," not associated with coal-seams as far as yet known. If this arrangement is correct, and my experience as a field geologist is entirely in its farour, it is of great practical value to us in Victoria in the search for workable coal-seams, and should cause us to direct our attention to the upper beds of the Avon series, Gipps Land, where No. 4 is so well developed, and also to Cape Liptrap, where Carboniferous Limestone is supposed to crop out, in the hope of finding the Glossopteris beds. It points unfarourably towards the Tenæopteris and $Z$ amites bearing beds, which we have hitherto regarded as our coal-producers, but which, as yet, have yielded nothing better than the Cape Paterson seams. 4000 feet also of these same beds have been tested by boring in the Bellerine district and have yielded nothing ap. proaching a workable seam.

In the collection of fossils forwarded by Mr. Clarke to Professor $\mathrm{M}^{\circ} \mathrm{Coy}$, at Cambridge, specimens had been collected from the three upper divisions of the Carboniferous series of New South Wales; the subsequent division of the group had not then been worked out by that indefatigable geolo. gist, and it is in this way, I believe, the mistake has arisen between $\mathrm{Mr}$. Clarke and Professor M'Coy. Whether the fauna that overlies Russell's coal-seams is most assimilated to the Palæozoic or Lower Mesozoic forms of Europe, is a question on which I am not competent to form an opinion. When the question shall have been settled by palæontological authorities, it seems to me that little will have been done for the physical geologist at the antipodes, who must trust to the order of superposition, rather than to the palæontology, to work out the order of sequence, holding the opinion of Professor Huxley, that "there is no escape from the admission, that neither physical geology nor palæontology possesses any method by which the absolute synchronism of two strata can be demonstrated. That the moment the geologist has to deal with large areas, or with completely se- parated deposits, then the mischief of confounding homotaxis, or similarity of arrangement which can be demonstrated, with synchrony or identity of date, for which there is not a shadow of proof, under the term of contemporaneity, becomes incalculable, and proves the constant source of gratuitous speculations." All the facts that we have to guide the fieldgeologist in Victoria in his search for Clarke's No. 3 Carboniferous beds (containing the workable seams of New South Waies) are these,- that they are very low down in the Carboniferous series; that the lowest beds contain a fauna nearly allied to the Lower Carboniferous of Europe; that Glossopteris is associuted with all the coal-seams, and is the most common and characteristic fossil of the said No. 3. This peculiar fauna or flora has not yet been observed in Victoria. Leaving now this most interesting piece of country and coasting along to Moreton Bay, under the lighthouse on Moreton Island we have sandstones, with a slight inclination, apparently, of the Carboniferous series cropping from under the Tertiary (?) sand of which the island is composed. If this is really Carboniferous Sandstone, Moreton Island may shortly become more valuable than its outward appearance would lead one to suppose. The rocks on which Brisbane stands may be referred to the Upper Silurian; they have generally a north-easterly dip at high angles, are traversed by numerous quartz veins, and gold would surely be found, though perbaps not in workable quantity, in the gullies around the city. If not covered by the Carboni- 
ferous series, as in the neighbourhood of Ipswich, we should expect richer deposits of gold in a south-westerly direction on getting into rocks lower in the Silurian series, that is supposing them still to retain their northeasterly dip. Passing out of Moreton Bay, and still going northerly, Tertiary sands of the Brighton series occupy low-lying country on the coast, the Glass House Peaks, said to be volcanic, raising their peaked heads from the plain with sharper outline than the craters of Ascension. At Double Island Point, the southern entrance of Wide Bay, Basalt underlies the Tertiary, and hence to Inskip Point are cliffs the exact counterpart in lithological character of the Red Bluff series, Brighton. The streets of Maryborough are metalled with soft sandstone, similar in appearance to the Melbourne beds, and fifteen miles in a south-westerly direction gold of a nuggety character is being found in quantity, and about a hundred diggers are employed.

Hence to Rockhampton the sandy tertiaries prevail along the coast. Under Woody Island, and at one point on Fraser's Island, Basalt is seen in places cropping from under the sand. Rockhampton stands on rocks which dip to the north-east at high angles. A quarry opened at the side of one of the streets exposes a fine section of these. They consist chiefly of altered slates with bands of impure limestone containing fossils, pronounced by Professor M'Coy as Palæozoic. The altered slates, almost Ly dian stone in places, resemble those of Mount Staveley, Victoria. No quartz reefs were noticed in them. In the range of hills opposite Rockhampton, these same beds have a westerly dip, and splendid sections are afforded of the sequence of beds in the heads of the creeks running from these hills. Up the Fitzroy, about four miles above Rockhampton, a marble is quarried for lime-burning ; it has a north-easterly dip, and appears to be nearly the uppermost stratum of the series exposed in the neighbourhood. Cornelians, some of large size, are found in the gravel drift of the Fitzroy at this point, probably washed from granitoid rocks exposed higher up that stream. Leaving Keppel Bay and going north among the islands, all is granite (Pentecost Island is one of the most remarkable in form). Generally they are pine-clad, and have a most picturesque appearance. The sail from Rockhampton to Port Denison is, indeed, one of the most charming it has yet been my fortune to undertake. Rounding Gloucester Island, a precipitous granite ridge, Port Denison, is reached.

The township of Bowen stands on Tertiary sand resting on a granitoid rock. The same geological feature extends along the coast northward to the Burdekin river, Cape Upstart, Mount Abbot, and numerous smaller peaks of granite rearing their heads above the Tertiary plains and alluvial swamps at their base; indeed, were the coast line submerged to the dividing range $200 \mathrm{ft}$. below the present level, it would present the same features as now obtain from the present shore to the Barrier Reef. At the lower crossing of the Burdekin, the cornelian-bearing granitoid rocks are again in force, and abundance of cornelians are to be found in the river sands. Following the present well-beaten track to the Valley of Lagoons at the head of the Burdekin-a track which twelve months ago did not exist, but is now as plain and well-worn as any in Victoria (the distances in miles marked on the trees)-for twenty-nine miles from the Lower Burdekin crossing, we pass over a level, sandy, Tertiary area, with large patches of swampy alluvium. At the twenty-seventh milestone Kill Bullock Creek is reached, on the east bank of which a well-defined quartz reef crops out from a matrix of rotten granite. This granite is exactly similar in eharacter to that of Omeo and that of some portions of Tambo 
River, Gipps Land. Frequently hornblende replaces the mica altogether ; it is then this rotten character is most observed, and the decomposition it: self has been so active in places, that at the forty-first milestone a freshwater deposit of white limestone has accumulated to a very considerable thickness. At the forty-second milestone the summit of the coast range is reached. Hence to the fifty-third milestone, the last crossing of the Fanning river, these same granitoid rocks prevail. In the bed of the Fanning river gold of rather coarse character has been found, both by Mr. Ross, of the Fanning, and a party of miners who accompanied Mr. Brown, of Sydney, to open a supposed copper-lode in the neighbourbood. [The specimen given me by Mr. Brown was examined by Mr. Wood, at the Geological laboratory, and found to be specular iron ore.] Now this is exactly the character of granite described by Mr. Clarke, of Sydney, as gold-bearing; in fact it was from the description in his 'Southern Goldfields,' that I was led to give more than ordinary attention to this area, in hope of getting at some practical result.

My time would not permit me to prospect for myself, but I am of opinion that a less lucrative employment might be found than gold-washing in Kill Bullock Creek, and from there to the Fanning river the geological indications are equally favourable, supposing it to be a fact that granite of this description, or even quartz reefs in granite, are the rnatrix of gold. It is true that on the top of the coast range boulder-pebbles of rocks foreign to those in situ are scattered over the surface of the ground, and although denudation over this area has been very great, still $I$ saw no sign of Silurian rocks in or near the Fanning; there are certainly none on the east side coast-range. This looks like one more example of the occurrence of "gold in granite." At about the seventieth mile from the Juwer Burdekin erossing, the granites give place to limestones full of corals, with a lithological character, the exact counterpart of those of Buchan and Bindi, Gipps Land; they are as much contorted as these, but their most regular dip is N. $30^{\circ}$, E. $50^{\circ}$. The samo physical outline is also here obtained, and Bindi, dotted with small clumps of serub, overgrown with many-tinted creepers, to give variety to the landscape, would serve for a photograph of Cunningham's Burdekin Station. These limestones were either very thin originally or they have been greatly denuded, since the granite crops at the surface at intervals till the Upper Burdekin crossing regularly stratified pink and brown sandstones and breccias make their appearance, dipping south-westerly at an angle of $10^{\circ}$ to $15^{\circ}$.

On the west side of the Burdekin, Basaltic lava veils the underlying rocks, but on crossing a deep cutting creek, six miles from the crossing place, these same pink sandstones occupy the bed of the creek, with a westerly dip at $15^{\circ}$. These sandstones I take to be the northerly exten. sion of the Carbonaceous series, which I have Mr. Gregory's authority for stating extend from the junction of the Suttor with the Burdekin to Darling Downs. The usual section on the Buckland table-land, according to this authority, is-1. Basalt; 2. Upper Carboniferous Sandstone; 3. Coalmeasures ; 4. Limestones, with spirifers. I am indebted to $\mathrm{Mr}$. Richardson, of Rockhampton (of Burne, Bassett, and Co.), for the information that a seam of coal $6 \mathrm{ft}$. thick crops in the banks of the Mackenzie, near Cooroorah station, with a general S.W. dip, resting unconformably on the conglomerates and sand stones of Mount Stewart.

From this Upper Burdekin crossing west to the watershed of the Flinders the country is entirely basaltic, Fletcher's Creek forming its main boundary on the south, and the Clarke river on the north, where the 
underlying rock is seen in the bed of "Basalt" or "Limestone" creek ; it is of a granitoid character, but Mount Caroline, the southernmost peak of Perry's Range, is of altered slate, highly inclined, with numerous and broad quartz reefs on the flanks, the summit being composed of syenite, and this appears to be the character of the rocks of the Upper Clarke, though blue fissile slate with quartz reefs is more abundant there. Mr. Clarke has long ago pointed out this district as a future gold-field. The fulfilment or otherwise of the prophecy is at hand. It was from drifts overlying the Basalts of this district I obtained the bones of Diprotodon, the most northern part of Australia in which, at present, the fossil remains of this animal have been found. It is to these drifts that the cattle in the neighbourhood come to lick, and I am of opinion it is more for the phosphates from the bones of Diprotodon and his allies than from the chlorides they contain.

A well-defined crater exists at a point bearing S. $30^{\circ} \mathrm{W}$. from Mount Caroline, distant 36 miles. From the top of this an excellent view is obtained of the boundary of the Basalt to the south. Granite spurs, gradually sloping to the southern side of Fletcher's Creek, have checked its further development in this direction.

Looking westward, we have a gradual rise to the table-land forming part of the watershed between the Flinders and Burdekin rivers, broken at intervals by low isolated peaks or ridges. From this point may be seen the Mount Mayne, etc., of Walker. South of this hill, about two miles, commences what is called a "Basalt wall." This is said to extend in a southeasterly direotion as far as, and across, Fletcher's Creek, and I believe no one had up to that period penetrated above this up Fletcher's Creek. Where I struck it it had the appearance of a walled city ruined by an earthquake, the outer wall, though much rent, preventing the access of a horseman to the débris lying within. Creepers and shrubs of great variety grew over all, whilst a swampy bog at the base of its bluff margin, rich in ferns, promised on the whole a harvest for the botanist, a safe retreat for the blackfellow, and charming "little bits" for the artist or photographer. I regret much that I could not devote the time to following down this "Basalt wall," and more thoroughly exploring it. Whether it is the margin of an enormous crater, or a more recent lava-flow than that of the surrounding level country, I had not leisure to investigate. These Basaltic Lavas differ in no respect from those of probably the same age in Victoria; a suite of specimens collected on Keilor Plains and on the Upper Burdekin could not be distinguished the one from the other. A peculiar feature of the Basaltic country here is, that the banks of the main, deepcutting creeks are very rocky, whilst the branch creeks are usually the drains of open, gently-sloping well-grassed downs ; table-lands of lightlytimbered and usually coarser-grassed country intervening between the branch creeks. The timber on these table-lands is chiefly that known as "stunted ironbark," and a remarkable feature is the absence of fallen timber. This is attributable to the fact that the centre of nearly all the trees is hollow, making them an easy and certain prey to the first bush-fire.

Taking a general view of the geology of Queensland, as far as could be obtained in such a flying visit, and from the reliable information I could collect, it would appear that a belt of Upper Silurian rocks extends along the coast from Brisbane to the neighbourhood of Broad Sound, and that their strike being nearly parallel with the coast line, has mainly determined its outline. Their dip, where observed, is north-easterly, at a high inclination. The Maryborough and Rockhampton beds I would place at about the same geological horizon; lower in the series would come the gold-fields 
of Canoona, and those south-westerly from Maryborough, and to the strip of country beween these two gold-fields we should look for the extension of diggings. From the fact of these rocks being, as I believe, Upper Silurian, gold-fields of the type of Caledonia and Anderson's Creek are to be expected rather than those of Sandhurst and Ballarat. Silurian rocks again make their appearance at Mount Caroline, the southernmost peak of Perry's Ranges, Upper Burdekin. On the flanks of this hill their general dip is south-westerly. These rocks I should consider about the horizon of the auriferous series of Peak Downs, and that they represent the western portion of a great anticlinal axis, of which the Canoona and Maryborough beds represent the eastern. The dome of this axis has been denuded, and gone to form a portion of the material of that enormous carboniferous deposit which, as Mr. Gregory informs me, extends from the junction of the Suttor with the Burdekin southward to Darling Downs. From Broad Sound northerly to Mount Elliot, the coast range is of granite and its varieties, and in streams flowing exclusively through the granite, auriferous drift is found.

Whether the extension of the Silurian system over this country has been entirely removed, and the granite represents only the base of this supposed anticlinal dome exposed by denudation (as the objectors to gold in granite would probably argue), is, of course, uncertain; this much at least can be said, that the drift in which this gold is found is essentially granitic, and the resemblance to the granites of Omeo and Tambo River, Gipps' Land, is remarkable. Basaltic lava flows, of greater or less extent, are met with in various parts of the colony, e.g. between the Clarke river and Fletcher's Creek, the Valley of Lagoons, the Buckland table-land, Peak Downs, etc. Between the 19th and 20th parallels of latitude the greater part of the country seems to be oc supied by it. The tract of country included between the Clarke and Fletcher's Creek has received its Basaltic covering from local craters, which form conspicuous landmarks only from high ground; they are too low to be seen in timbered country. The Basaltic areas are those best adapted for pastoral purposes in the tropics, their rich soils inducing the growth of the finer grasses with abundance of herbs, whilst their elevation above the sea renders the climate less enervating than that of the seaboard. From Mr. A. C. Gregory I learn that the representatives of our "older Basalts" of Philip Island, Cape Schank, etc., are found as dykes cutting through the Carboniferous series, and he draws the distinction (which holds in Victoria) between the Basaltic lavas of the plains and these, that the former were ejected from individual craters, the latter from fissures, forming dykes in rocks they traversed.

The geology of Queensland, therefore, seems to differ little from that of Victoria, except in the relative areas occupied by each formation, the neighbourhood of Fitzroy Downs, from which the Wollumbilla fossils have been received, affording the only prospect of novelty to the Victorian geologist.

\section{NOTES AND QUERIES.}

Devonians in North-East France.-It is well known that the Deronian rocks of the Meuse extend towards the Boulonnais, and are connected with that enormous line of dislocation and upheaval which has brought up the coal-measures and subjacent rocks in a direction from 